\title{
The Impact of practice Strategic Adaption on \\ Economic Crisis Management Strategies under the Circumstances of War - Syrian Case from 2011 to 2018
}

\author{
Orwa Mahmoud Al Zoubi \\ collage of Business Management and Economics \\ Salzburg University in Austria
}

\begin{abstract}
The present study aimed to identify the impact of practice strategic adaption on economic crisis management strategies under the circumstances of the Syrian war, identifying the procedures, which the ministries took to address the present economic crisis and determine the obstacles, which faced the ministries in managing the crisis. The study used a descriptive analytical method, where (172) questionnaires distributed to respondents who occupied upper and middle administrative positions at six governmental ministries and institutions in Syria. The study revealed a statistically significant impact of practice strategic adaption on economic crisis management strategies, and that some procedures have been taken such as: Prevent the importation of many products that consume foreign exchange reserves such as new cars and luxury products, Reliance on private sector companies to import materials that the Syrian government is not allowed to import due to economic sanctions and opening a credit line with Iran worth one billion dollars to provide oil derivatives and other goods. The study recommended forming a committee of senior experts from the six ministries to develop adaptive strategies for managing the crisis and review them periodically every 6 months and reducing the domestic demand of foreign exchange through control of imports, seizure of smuggling operations, and speculation.
\end{abstract}

Keywords: Crisis Management, Strategic Adaption, Syrian War.

\section{Framework of the Study}

\subsection{Introduction}

The countries can face unprecedented situations of constant challenges and rapid changes in the shadow of crisis, which in turn impose a series of severe obstacles affecting the economic and financial situation of the state and the people. The country'ssuccess in surviving in the shade of these conditions depends on flexibility and adaptation to rapid changes and finding quick solutions to the problems and challenges it face and developing flexible strategies enable it to manage successive crises (Coombs, 2012). And crisis management represents the methodology which through it could dealing with the crisis in the light of knowledge, awareness, available capabilities, skills and prevailing management patterns (Al Sairafi, 2008).

There is no doubt that the crises, especially the wars leave a devastating impact on the economic, social and political life of countries, and the nature of managing the crisis by government plays a big role in aggravation the crisis or mitigation its effect, and the Syrian war is a vivid example of the severe crises that can be experienced by countries. In this sense, the researcher sought to study the Syrian situation to take advantage of the lessons learned and to highlight the ability of the Syrian government to adapt strategically to the conditions of war and surviving and the extent to which it adopts flexible strategies to manage the economic crisis.

\footnotetext{
* This article was submitted in October 2019, accepted for publishing in November 2019 and published on December 2019.

(c) Arab Administrative Development Organization- League of Arab States, 2019, pp 265-272، DOI: 10.21608/aja.2019.66954
} 


\subsection{Problem of the study}

The economies of many countries are exposed to crises, varying in severity as a result of many reasons, whether economic, political or social, and the method of governments' treat with these crises differs from country to another according to the extent of their experience and vigilance to the crises, and the nature of their prevailing economy. And the current Syrian crisis is one of the biggest crises and the most dangerous in the modern era, which has had a significant impact on many countries economically and politically such as, European countries, Lebanon, Jordan, Turkey and Iraq. And remarkably, that the Syrian economy is still standing after intensive and hard seven years and could adapt with the circumstances of the war, unlike many countries that suffered a major collapses in their economy as a result of exposure to similar conditions as Iraqi, Lebanon, Libya, Rwanda, Somalia ...etc. In this sense, the researcher seeks to conduct a thorough research to highlight on Syrian experience in managing the economy and its success in preventing the collapse of the economy through adopting flexible strategies under the circumstances of the Syrian war. Therefore, the present study tries to answer the following questions:

- What is the practice level of strategic adaption by the Syrian governmental ministries/ institutions?

- What is the practice level of economic crisis management strategies by the Syrian governmental ministries/ institutions?

- What is the impact of practice strategic adaption on economic crisis management strategies under the circumstances of the Syrian war?

- What are the procedures, which the ministries/institutions have taken to address the present economic crisis?

- What are the obstacles, which have faced the ministries/ institutions in managing the crisis?

\subsection{Hypothesis of the study}

the current study tests the following hypothesis:

$\mathrm{H}$. There is a positive correlation between practice strategic adoption and economic crisis management strategies under the circumstances of the Syrian war.

\subsection{Objectives of the study}

The present study seeks to achieve the following objectives:

- In order to identify the practice level of strategic adaption by the Syrian governmental institutions.

- To specify the practice level of economic crisis management strategies by the Syrian governmental institutions.

- In order to know the impact of practice strategic adaption on economic crisis management strategies under the circumstances of the Syrian war.

- Identifying the procedures, which the ministries have taken to address the present economic crisis.

- Determine the obstacles, which have faced the ministries in managing the crisis.

\subsection{Significance of the study}

the current study comes to highlight on the Syrian model in managing the economy in light of the crises that can infect the countries, where this study gains its importance through two sides:

- Theoretical Significance: This study acquires its theoretical importance through lack of studies 
related to managing the economic crises under the circumstances of war comparison with other managerial studies. In addition to the subject of the study is one of the pressing and required topics at moment, where a number of countries around the world are likely to experience political and social upheavals that threaten severe economic crises.

- Practical Significance: The importance of this study emerges from the geostrategic importance of Syria as a country links between three continents, Asia, Africa and Europe, and its location in an area considered the primary supplier of oil in the world. Thus, the current crisis must leave negative impacts on many surrounding countries. Moreover, the results and recommendations of the study are hoped to contribute to assist decision-makers in Syrian government or other governments around the world interested in Syrian crisis or humanitarian organizations relevant Syrian crisis to make decisions that can mitigate the effects and repercussions of Syrian crisis economically and socially. And to provide lessons learned to manage economic crises in times of wars.

\subsection{Model of the study}
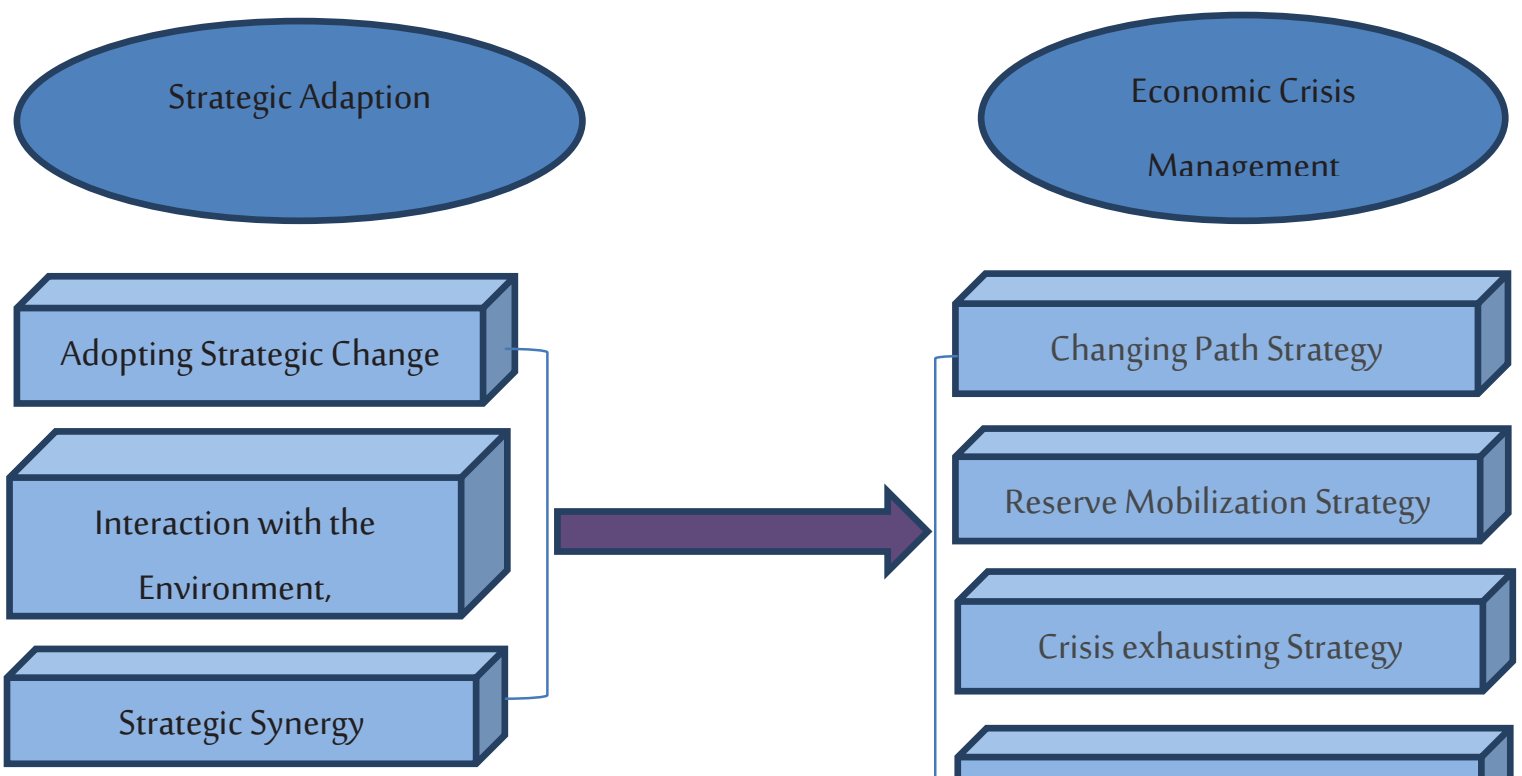

Reserve Mobilization Strategy

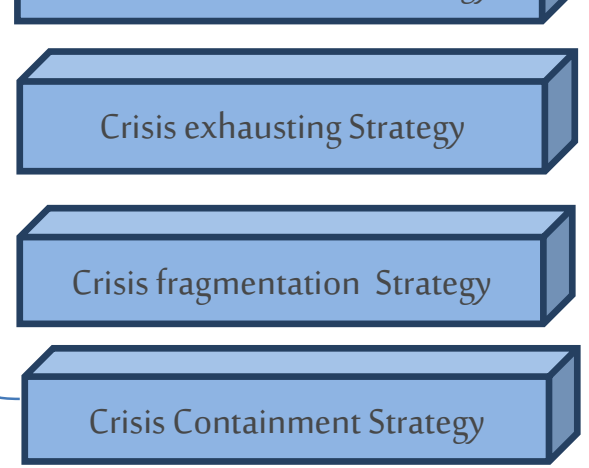

Independent Variable

Source: developed by the author based on (Tayauova, 2011,. Gilpin \& Murphy, 2008)

Dependent Variable

Figure (1): Model of the Study

\subsection{Definitions of the study terms}

Crises management: Which is the strategic planning of crises by the use of scientific and practical tools during the various stages of the crisis, in order to address it and trying to control it to avoid the negative sides and take advantage of its positives (Fearn-Banks, 2007). It is procedurally defined in this study: The strategies and measures taken by the Syrian governmental ministries to contain the current crisis and overcome the difficulties and risks faced. 
Strategic Adaption: The ability to foresee the risks and future, internal and external problems, and knowing the means to control them as much as possible (Mykhailivna, 2016). It is procedurally defined: The ability of Syrian government to predict the risks and adapt with the new circumstances in the shadow of war.

\section{Literature Review}

The Syrian economy has been subjected to unprecedented fundamental imbalances, where there has been a significant decline in productivity of the production factors, as there has been a deterioration in human capital, which is the main source of productivity and competitiveness due to migration, the decline in the educational process and the deterioration of the health system in the country, in addition to the lack of physical and operational investment especially in hot spots. The Syrian economy has witnessed a dramatic shift in its overall indicators, as the crisis has cast a shadow over the GDP and the state budget, and has increased the pressures on the population's living level and has risen the external and internal debt to record levels after Syria was ranked among the least indebted countries in the world. The total loss of GDP during the crisis years amounted to 81 billion distributing to the various economic sectors. This loss is equivalent to $212 \%$ of the gross domestic product (GDP) for the year 2015 , as the loss was distributed to the economic sectors as follows: the industrial and mining sector (50\%), the wholesale and retail trade sector $(18.7 \%)$, the transport and storage sector $(9.9 \%)$, agriculture sector $(9.8 \%)$ and the rest of sectors (11.6\%). However, the Syrian economy was able to adapt to the crisis, as some sectors achieved good growth rates compared with the beginning of the crisis, especially after the improvement of the security situation in the country (Damascus center for research and studies, 2016).

According to a new study was done by the World Bank on the economic situation in Syria (2018), it found that damage to productive factors and economic activity has been extensive, damaging capital stock (e.g. about one-third of housing stock and one half of health and education facilities damaged or destroyed),while disrupting economic activity. From 2011 to 2016, cumulative GDP loss is estimated at $\$ 226$ billion. In addition, Disruptions in economic organization are the most important driver of the economic impact, superseding physical damage. Conflict has disrupted economic activity by diminishing economic connectivity, reducing incentives to pursue productive work, and disconnecting networks and supply chains. Cumulative GDP loss due to disruptions in economic organization exceeds that of physical destruction by a factor of 20 . This contrast is explained by how the economy reacts to different shocks. A "capital destruction only" is like some natural disasters: in a well-functioning economy, its effects on investment are limited (-22\% in simulations) as capital can be rapidly rebuilt and repercussions contained. In comparison, economic disorganization reduces investments significantly (-80\% in simulations); and effects propagated over time.

Despite the massive negative effects and the sharp decline in the economic indicators, a lot of the economists believe that the Syrian economy has been able to continue and has not collapsed, where Gardi (2017) argues that the success of the economy to survive is an economic miracle in the harsh conditions experienced by the country, which is attributed to four main reasons:

- The long experience gained in dealing with the economic sanctions and the conditions of the siege, as happened during the 1980s.

- Economic support by friendly countries such as Iran and Russia.

- Diversity of the Syrian economy enabled the state to reach self-sufficiency in most economic sectors before the war.

- The existence of a shadow economy, which activates at the time of crisis. 
The existence of a good reserve of strategic goods before the crisis.

A number of studies have been conducted on the subject of the present study, where Jaffar (2017) conf ducted a study aimed to identify the impact of strategic planning in crisis management at public institutions in Jerusalem suburbs in Palestine for minimizing the risks and crises facing public institutions. The descriptive analytical method was used through a questionnaire was distributed to 850 employees. The results of the study showed that the strategic planning in public institutions contributed to the reduction of the potential problems and that the lack of explanation introducing to the employees declined the effectiveness of crises management. Moreover, the lack of employees' involvement in a strategic planning was an obstacle to solving problems. Abu Rumman (2016) in his study linked between exercising transformational leadership and ready to manage crisis at the Arab Potash Company and the Jordan Phosphate Mines Company. The study sample was composed of (359) male and female workers from the two companies. The results revealed that the exercise of the transformational leadership accounts for (64.1\%) of the crisis management preparedness and the most effective transformational leadership in crisis management preparedness is the empowerment dimension followed by the individual consideration then the brainstorming dimension.

On the other hand, Janssen \& Brumby (2015) accomplished a study to investigate how individuals in their multiple tasks can adapt with new strategies and adopt an optimal strategy to achieve the tasks assigned to them. The study was conducted on (24) participants working in dual-tasking companies. It found that the change in tasks and monetary compensations together affected the strategy adopted by individuals in achieving the tasks entrusted to them, and that the change in the adopted strategy affected their performance levels in each task, the matter which reflected in the final result on the overall performance of the Organization. Lusia (2013) discussed how organizations deal with crises management and confront them according to their nature. The study used the methodology of historical research in previous studies and methods of managing past crises and how to deal with them, as they were divided into two main types: natural crises and man-made crises. The results revealed that members of organizations have to understand the steps of crises management and develop appropriate strategies and leadership models for managing crises effectively, and organizations should evaluate existing strategies before building new ones. Furthermore, Al Kubaisy and Hussien (2013) conducted a study aimed to determine the role of strategic planning in effectiveness of crisis management over the stages of its management. The sample consisted of (76) managers in the ministry of planning in Iraq. The results found that the ministry of planning used strategic planning with all its indicators for managing crisis and found that the contribution of change in strategic planning in order to achieve positively change in effectiveness of crisis management increased over the stages of crisis management . In turn, Tayauova (2011) conducted a study to examine the relationship between the international entrepreneurial orientation and the strategic adaptation of the companies in Kazakhstan and Kyrgyzstan. The study sample consisted of 114 managers and owners of Turkish companies in two countries. The researcher used the analytical descriptive method through a questionnaire. The study showed a Positive relationship among the dimensions of international entrepreneurial orientation and the strategic adoption of Turkish companies working in Kazakhstan and Kyrgyzstan. Also, (Unlu., et al, 2010) fulfilled a study aimed to clarify the extent of evolution of the crisis and disaster management systems of the government and the Turkish system. The study concluded a governmental failure in the field of crisis management, as the Turkish system has a significant problem of coordination and organizing, where there is no clear mechanism for cooperation and management among the institutions working in crisis and disaster management. This causes duplication in the system, and therefore plans and actions fail in the case of implementation. Regarding crises management, Brent (2004) executed a study titled "Chaos, crises and disasters: A strategic Approach to crises management in the tourism industry" which focused on the strategic approach to crisis management. The results of the study exposed the need of tourism organizations to flexibility, continuous monitoring and design and implementing effective strategies to deal 
with crises, the study emphasized the need of organizations to use holistic approach to crisis management and restructuring their administrative structures.

\section{Methodology of the Study}

The present study relied on the analytical descriptive approach, through the literature related to strategic adoption and the crisis management, which are available in books, articles, previous studies and published studies. In addition to data collected from the field by a questionnaire designed and distributed to the study sample to cover the surveyed areas and its dimensions. For this purpose, the researcher formed an assistant research team is consisting of (5) members to help the researcher to distribute the questionnaire to study sample and answer the open two questions.

\subsection{Participants}

The study population consisted of all employees at six Syrian government ministries and institutions, which are responsible directly for managing the Syrian economy and drawing the economic policies of the state, including: Ministry of Finance, Ministry of Economy and Foreign Trade, Ministry of internal Trade and Consumer Protection, Ministry of Industry, State Planning Commission and Central Bank of Syria, whereas the study sample consisted of the employees at upper and middle administrative positions at those ministries under job title (General Manager, Assistant / Deputy General Manager, Head of main department, head of department), and their number (172) employees, according to the Department of Personnel at each ministry and institution. Upper and middle administrations were selected as a study sample, because adopting the economic strategies are done at those two administrations.

\subsection{Instrument reliability}

In order to investigate the reliability of the questionnaire, the internal consistency coefficient (Cronbach's Alpha) calculated on a survey sample from outside the study sample (30). Table (1) below shows that the coefficients are suitable for the purpose of conducting the study, because all coefficients are higher than 0.68

\section{The Findings and Recommendations}

\subsection{The functional characteristics}

The number of questionnaires distributed to the study sample was (172) questionnaires, while the number of questionnaires retrieved and valid for the purposes of analysis was (116) questionnaire with a rate of recovery (67.44\%). Table (2) shows the frequencies and percentages of the functional characteristics of the sample of the study as the following:

\subsection{Answer of the questions}

The first question: What is the practice level of strategic adaption by the Syrian governmental ministries/institutions?
Table (1)

Cronbach's Alpha

\begin{tabular}{lc}
\hline \multicolumn{1}{c}{ Dimensions } & $\begin{array}{c}\text { Cronbach's } \\
\text { Alpha }\end{array}$ \\
\hline Adopt strategic change & 0.88 \\
\hline Interaction with the environment & 0.82 \\
\hline Strategic synergy & 0.79 \\
\hline Strategic adaption as a whole & $.85 \cdot$ \\
\hline Changing Path Strategy & $.84 \cdot$ \\
\hline Crisis Fragmentation Strategy & 0.73 \\
\hline Crisis containment strategy & 0.91 \\
\hline Crisis exhausting strategy & $.77 \cdot$ \\
\hline Reserve mobilization strategy & .82. \\
\hline Economic crisis management as & $.87 \cdot$ \\
a whole & \\
\hline
\end{tabular}


Table (2)

Frequencies and percentages according to the study variables

\begin{tabular}{llcc}
\hline & Categories & Frequencies & Percentages \\
\hline \multirow{3}{*}{ Job Title } & General Manager & 3 & $2.59 \%$ \\
\cline { 2 - 4 } & Assistant / Deputy General Manager & 14 & $12.07 \%$ \\
\cline { 2 - 4 } & Head of the main department & 28 & $24.14 \%$ \\
\cline { 2 - 4 } & head of the department & 71 & $61.20 \%$ \\
\hline \multirow{2}{*}{ Institution name } & Ministry of Finance & 13 & $11.21 \%$ \\
\cline { 2 - 4 } & Ministry of Economy and Foreign Trade & 20 & $17.24 \%$ \\
\cline { 2 - 4 } & Ministry of internal Trade and Consumer Protection & 27 & $23.28 \%$ \\
\cline { 2 - 4 } & Planning and international cooperation Commission & 21 & $18.10 \%$ \\
\cline { 2 - 4 } & Ministry of Industry & 26 & 22.41 \\
\cline { 2 - 4 } & Central Bank of Syria & 9 & 7.76 \\
\hline Total & & 116 & $100 \%$ \\
\hline
\end{tabular}

In order to answer this question, means and standard deviations of the practice level of strategic adaption by Syrian governmental institutions were found, and table (3) below presents that.

Table (3) displays that the general level of practice strategic adaption by Syrians governmental institutions is moderate with mean (3.50). It also represents that the means range between (3.04) and (3.95), as that the dimension "strategic synergy" places first with the highest mean (3.95)

Table (3)

Means and standard deviations of the level of strategic adaption

\begin{tabular}{llrll}
\hline $\mathrm{N}$ & Dimensions & Mean & $\begin{array}{c}\text { Std. } \\
\text { Deviation }\end{array}$ & The level \\
\hline 1 & Adopting strategic change & 3.52 & .75. & Moderate \\
\hline 2 & Interaction with the environment & 3.04 & .77. & Moderate \\
\hline 3 & Strategic synergy & 3.95 & .89. & High \\
\hline & Strategic adaption as a whole & 3.50 & & Moderate \\
\hline
\end{tabular}
and a high level, followed by the second dimension " adopting strategic change " with a mean (3.52) and a moderate level, while the dimension "interaction with the environment " comes at last with a mean (3.04) and a moderate level. The table above also shows that the standard deviations range between (0.75) and (0.89), and that indicates to the responses convergence of the study sample.

\section{a- Adopting strategic change}

Table (4)

Means and standard deviations of adopting strategic change

\begin{tabular}{llccc}
\hline $\mathbf{N}$ & \multicolumn{1}{c}{ Items } & Mean & Std. Deviation & The level \\
\hline 1 & The ministry/institution draws multiple scenarios to prepare for change. & 3.45 & .86. & Moderate \\
\hline 2 & $\begin{array}{l}\text { The ministry/institution creates strategies to counter the changeable conh } \\
\text { ditions. }\end{array}$ & 3.97 & .92 . & High \\
\hline $3 \begin{array}{l}\text { The ministry/institution's operations enable to make decisions quickly } \\
\text { when conditions change. }\end{array}$ & 3.32 & .76 . & Moderate \\
\hline $\begin{array}{l}\text { The ministry/institution conducts a survey of the work environment to } \\
\text { reduce the threats it faces. }\end{array}$ & 3.27 & .89 . & Moderate \\
\hline $\begin{array}{l}\text { The ministry/institution utilizes its resources to respond to the opportunit } \\
\text { ties available. }\end{array}$ & 3.62 & .64 . & Moderate \\
\hline \begin{tabular}{l} 
Adopting strategic change as a whole \\
\hline
\end{tabular} & 3.52 & & Moderate \\
\hline
\end{tabular}


Table (4) demonstrates that the general level of adopting strategic change as a whole is moderate, as the mean is (3.52). It is an obvious also that the means range between (3.27) and (3.97), since that the item» The ministry/ institution creates strategies to counter the changeable conditions» locates first with the highest mean (3.97) and a so high level. The item "The ministry/ institution utilizes its resources to respond to the opportunities available" came second with a mean (3.62) and a moderate level, whereas the item "The ministry/ institution conducts a survey of the work environment to reduce the threats it faces." comes third with a Mean (3.27) and a moderate level. The table above presents that the standard deviations range between (0.64) and (0.92), and that refers to the responses convergence of the study sample.

\section{b- Interaction with the environment}

Table (5)

Means and standard deviations of interaction with the environment

\begin{tabular}{|c|c|c|c|c|}
\hline $\mathbf{N}$ & Items & Mean & Std. Deviation & The level \\
\hline 6 & $\begin{array}{l}\text { The ministry/institution collects information about the external environe } \\
\text { ment. }\end{array}$ & 3.77 & .98 & High \\
\hline 7 & $\begin{array}{l}\text { The ministry/ institution owns systems to exchange information from } \\
\text { the external environment. }\end{array}$ & 3.02 & .72 . & Moderate \\
\hline 8 & $\begin{array}{l}\text { The ministry/institution encourages employees to interact with their } \\
\text { external environment }\end{array}$ & 2.79 & .83 . & Moderate \\
\hline 9 & $\begin{array}{l}\text { The ministry/institution provides adequate resources of its tasks and } \\
\text { activities for interaction with the external environment }\end{array}$ & 2.85 & 1.08 & Moderate \\
\hline 10 & $\begin{array}{l}\text { The ministry/institution develops the employees' knowledge whom } \\
\text { perform activities of interaction with the external environment. }\end{array}$ & 2.80 & .80 & Moderate \\
\hline & Interaction with the environment as a whole & 3.04 & & Moderate \\
\hline
\end{tabular}

According to table (5), it is a lucid that the general level of interaction with the environment as a whole is moderate, where the mean is (3.04). The means range between (2.79) and (3.77), as the item» The ministry/ institution collects information about the external environment»comes first with the highest mean (3.77) and a high level, followed by item "The ministry/ institution owns systems to exchange information from the external environment. " which places second with a mean (3.02) and a moderate level. At last the item "The ministry/institution encourages employees to interact with their external environment " comes with a mean (2.79) and a moderate level. Table (5) also shows that the standard deviations range between (0.72) and (1.08), and that refers to the responses convergence of the study sample about the items except the item (9).

\section{c- Strategic Synergy}

Table (6)

Means and standard deviations of strategic synergy

\begin{tabular}{lcccc}
\hline $\mathbf{N}$ & \multicolumn{1}{c}{ Items } & Mean Std. Deviation & The level \\
\hline $\begin{array}{l}\text { Individuals working in the ministry from various levels Cooperating to accom- } \\
\text { plish complex tasks in hard circumstances. }\end{array}$ & & .94 & High \\
11 The ministry/institution's departments share efforts in order to face risks and threats. & 3.87 & .66. & High \\
\hline 12 The ministry's departments keeps open communications between each other. & 3.95 & .78. & High \\
\hline 14 The ministry conducts effective communication and alliances with friendly & 4.06 & 0.81 & High \\
countries to obtain their support and benefit from their experience & & & \\
\hline Strategic Synergy as a whole & 3.95 & & High \\
\hline
\end{tabular}


The results of table (6) illustrate that the general level of strategic synergy as a whole is high, because the mean is (3.95). The means range between (3.87) and (4.06), where the item» The ministry conducts effective communication and alliances with friendly countries to obtain their support and benefit from their experience»takes the lead with the highest mean (4.06) and a high level, secondly the item "The ministry's departments keeps open communications between each other " places with a mean (3.95) and a high level, whereas the item "The ministry/institution's departments share efforts in order to face risks and threats" comes finally with a mean (3.87) and a high level. The table above also presents that the standard deviations range between (0.66) and (0.84), which means the responses convergence of the study sample about the items.

The second questions: What is the practice level of economic crisis management strategies by the Syrian governmental ministries/ institutions?

In order to answer this question, means and standard deviations of the practice level of economic crisis management strategies by the Syrian governmental institutions were found, and table (7) below represents that.

Table (7) displays that the general level of economic crisis management strategies by Syrians governmental institutions is moderate with mean (3.54). It also represents that the means range between (3.05) and (3.91), as that the dimension «crisis exhausting strategy» comes first with the highest mean (3.91) and a high level, followed by the second dimension "crisis fragmentation strategy" with a mean (3.77) and a high level, while the dimension "crisis containment strategy" comes at last with a mean (3.05) and a moderate level. Table (7) above also shows that the standard deviations range between (0.70) and (1.04), which indicates to the responses convergence of the study sample except dimension (5).

\section{a- Changing Path Strategy}

Based on the results of table (8), it is a clear that the general level of changing path strategy as a whole is moderate with mean (3.60). The means rank between (3.09) and (4.12), as the highest level of applying is with the item (The ministry/ institution changes its approach with the current crisis according to its intensity at each stage) with a mean (4.12) and a high level, whereas the item (The ministry/ institution applies a changing path strategy to face the challenges of the current economic crisis) places second

Table (7)

Means and standard deviations of the level of economic crisis management strategies

\begin{tabular}{|c|c|c|c|c|}
\hline$N$ & Dimensions & Mean & Std. Deviation & The level \\
\hline 1 & Changing Path Strategy & 3.60 & 0.91 & Moderate \\
\hline 2 & Reserve Mobilization Strategy & 3.39 & 0.82 & Moderate \\
\hline 3 & Crisis Exhausting Strategy & 3.91 & 0.96 & High \\
\hline 4 & Crisis Fragmentation Strategy & 3.77 & 0.70 & High \\
\hline \multirow[t]{2}{*}{5} & Crisis Containment Strategy & 3.05 & 1.04 & Moderate \\
\hline & $\begin{array}{l}\text { Economic crisis manage- } \\
\text { ment strategies as a whole }\end{array}$ & 3.54 & & Moderate \\
\hline
\end{tabular}

Table (8)

Means and standard deviations of changing path strategy

\begin{tabular}{|c|c|c|c|c|}
\hline$N$ & Items & Mean & Std. Deviation & The level \\
\hline 15 & $\begin{array}{l}\text { The ministry/ institution applies } \\
\text { a changing path strategy to face } \\
\text { the challenges of the current } \\
\text { economic crisis. }\end{array}$ & 3.73 & 0.87 & High \\
\hline 16 & $\begin{array}{l}\text { The changing path strategy has } \\
\text { a positive impact on the perfor- } \\
\text { mance of the ministry's work. }\end{array}$ & 3.09 & 1.16 & Moderate \\
\hline 17 & $\begin{array}{l}\text { The ministry/ institution changi } \\
\text { es its approach with the current } \\
\text { crisis according to its intensity } \\
\text { at each stage. }\end{array}$ & 4.12 & .88 . & High \\
\hline 18 & $\begin{array}{l}\text { The ministry/ institution perit } \\
\text { odically reviews its applicable } \\
\text { strategies. }\end{array}$ & 3.48 & .69 . & Moderate \\
\hline & Chaning path strategy as a whole & 3.60 & & Moderate \\
\hline
\end{tabular}


with a mean (3.73) and a high level. At last is the item (The changing path strategy has a positive impact on the performance of the ministry's work) with a mean (3.09) and a moderate level. The table also shows that the standard deviations range between (0.69) and (1.16), which means the responses convergence of the study sample about the items, except the item (16).

\section{b- Reserve Mobilization Strategy}

Table (9) shows that the general level of reserve mobilization strategy as a whole is moderate with mean (3.39). The means rank between (3.22) and (3.51), as the item (The ministry/ institution prepares contingency plans for addressing the intensive shortage of resources) places first with a mean (3.51) and a moderate level, whereas the item (The ministry/ institution has sufficient cash reserves to counter the repercussions of the current crisis) comes at last with a mean (3.22) and a moderate level. The table also presents that the standard deviations range between (0.72) and (0.92), which means the responses convergence of the study sample about the items, because all values are converged and less than 1.00

\section{c- Crisis Exhausting Strategy}

The results of table (10) experience that the general level of crisis exhausting strategy as a whole is high, as the mean is (3.91). The means range between (3.40) and (4.23), since the item «The ministry recognizes the existence of the crisis in order to ensure that it is properly addressed.» signs the first place with the highest mean (4.23) and a high level, whereas the item "The ministry/ institution analyzes the content and dimension of the crisis for exhausting it» locates finally with a mean (3.40) and a moderate level. The table above also presents that the standard deviations range between (0.85) and (1.10), which refers to the responses convergence of the study sample about the items except the item (23).

\section{d- Crisis Fragmentation Strategy}

The results of table (11) demonstrate that the general level of crisis fragmentation strategy as a whole is high, as the mean is (3.77). The means range between (3.32) and (4.36), since the item» The ministry/ institution has sufficient information about the nature of the crisis it faces» takes the first place with the highest mean (4.36) and a high level, followed by the item "The ministry/ institution relies on experts and
Means and standard deviations of reserve mobilization strategy

\begin{tabular}{|c|c|c|c|c|}
\hline $\mathbf{N}$ & Items & Mean & Std. Deviation & The level \\
\hline & $\begin{array}{l}\text { The ministry/ institution had } \\
\text { sufficient reserves of materials } \\
\text { and human resources before the } \\
\text { crisis helped it to cope with the } \\
\text { repercussions of the current crisis }\end{array}$ & 3.45 & 0.86 & Moderate \\
\hline 20 & $\begin{array}{l}\text { The ministry/ institution has suffit } \\
\text { cient cash reserves to counter the } \\
\text { repercussions of the current crisis }\end{array}$ & 3.22 & 0.72 & Moderate \\
\hline & $\begin{array}{l}\text { The ministry/institution prepares } \\
\text { contingency plans for addressing } \\
\text { the intensive shortage of resources. }\end{array}$ & 3.51 & 0.92 & Moderate \\
\hline & $\begin{array}{l}\text { reserve mobilization strategy as } \\
\text { a whole }\end{array}$ & 3.39 & & Moderate \\
\hline
\end{tabular}

Table (10)

Means and standard deviations of crisis exhausting strategy

\begin{tabular}{|c|c|c|c|c|}
\hline$N$ & Items & Mean & I. Deviation & The level \\
\hline 22 & $\begin{array}{l}\text { You believe that crisis exhausting } \\
\text { strategy is suitable for treating } \\
\text { the crisis. }\end{array}$ & 4.12 & 0.93 & High \\
\hline 23 & $\begin{array}{l}\text { The ministry/ institution anas } \\
\text { lyzes the content and dimension } \\
\text { of the crisis for exhausting it. }\end{array}$ & 3.40 & 1.10 & Moderate \\
\hline 24 & $\begin{array}{l}\text { The ministry recognizes the } \\
\text { existence of the crisis in order } \\
\text { to ensure that it is properly } \\
\text { addressed. }\end{array}$ & 4.23 & 0.85 & High \\
\hline & $\begin{array}{l}\text { Crsis exhausting strategy as a } \\
\text { whole }\end{array}$ & 3.91 & & High \\
\hline
\end{tabular}


specialists to break up the current crisis" with a mean (3.88) and a high level, whereas the item "The ministry divides the crisis into parts and deals with each part to facilitate the resolution of the crisis as a whole. " falls finally with a mean (3.32) and a moderate level. Table (11) above also presents that the standard deviations range between (0.59) and (0.81), which refers to the responses convergence of the study sample about the items, because all values are converged and less than 1.00

\section{e- Crisis Containment Strategy}

Table (12) represents that the general level of crisis containment strategy as a whole is moderate, as the mean is (3.05). And the means range between (2.29) and (3.90), as the item "The ministry/ institution could contain the crisis over the last years». locates first with the highest mean (3.90) and a high level, followed by the item «All employees in the ministry/ institution commit measures taken to contain the crisis» with a mean (2.87) and a moderate level, while the item «The ministry/ institution is negotiating with some of the parties contributing to the current crisis» comes finally with a Mean (2.29) and a low level. The table also shows that the standard deviations range between (0.86) and (1.21), where the items $(29,32)$ refer to the responses convergence of the study sample about the items, whereas the rest of items indicate to the responses divergence about the these items, because both are higher than 1.00

The third question: What is the impact of practice strategic adaption on economic crisis management strategies under the circumstances of the Syrian war?

In order to answer this question, Simple Linear Regression was used for the practice level of strategic adaption on the practice level of economic crisis management strategies by Syrian governmental institutions, as shown in the following table.

Dependent Variable: economic crisis management strategies
Table (11)

Means and standard deviations of crisis fragmentation strategy

\begin{tabular}{|c|c|c|c|c|}
\hline $\mathrm{N}$ & Items & \multicolumn{3}{|c|}{ Mean Std. Deviation The level } \\
\hline 25 & $\begin{array}{l}\text { The ministry/ institution has } \\
\text { sufficient information about the } \\
\text { nature of the crisis it faces. }\end{array}$ & 4.36 & 0.59 & High \\
\hline 26 & $\begin{array}{l}\text { The Ministry/ institutionconducts } \\
\text { the necessary studies for deter- } \\
\text { mine the main conflicting factors } \\
\text { causing the crisis. }\end{array}$ & 3.54 & 0.75 & Moderate \\
\hline 27 & $\begin{array}{l}\text { The ministry/ institution relies on } \\
\text { experts and specialists to break } \\
\text { up the current crisis. }\end{array}$ & 3.88 & 0.81 & High \\
\hline 28 & $\begin{array}{l}\text { The ministry divides the crisis } \\
\text { into parts and deals with each } \\
\text { part to facilitate the resolution of } \\
\text { the crisis as a whole. }\end{array}$ & 3.32 & 0.77 & Moderate \\
\hline & $\begin{array}{l}\text { Crsis fragmentation strategy as a } \\
\text { whole }\end{array}$ & 3.77 & & High \\
\hline
\end{tabular}

Table (12)

Means and standard deviations of crisis containment strategy

\begin{tabular}{|c|c|c|c|c|}
\hline $\mathrm{N}$ & Items & \multicolumn{2}{|c|}{ Mean Std. Deviation } & The level \\
\hline 29 & $\begin{array}{l}\text { The ministry/ institution } \\
\text { depends on work teams inside it } \\
\text { for containing the crisis. }\end{array}$ & 2.97 & 0.86 & Moderate \\
\hline 30 & $\begin{array}{l}\text { All employees in the ministry/ } \\
\text { institution commit measures } \\
\text { taken to contain the crisis }\end{array}$ & 3.07 & 1.21 & Moderate \\
\hline 31 & $\begin{array}{l}\text { The ministry/ institution could } \\
\text { freeze the crisis at specific extent } \\
\text { for containing the crisis }\end{array}$ & 3.90 & 1.03 & High \\
\hline & $\begin{array}{l}\text { The ministry/ institution is } \\
\text { negotiating with some of the } \\
\text { parties contributing to the } \\
\text { current crisis. }\end{array}$ & 2.29 & 0.91 & Low \\
\hline
\end{tabular}

Crsis containment strategy as a $3.05 \quad$ Moderate whole 
Table (13) illustrates a statistically significant impact at the level of $(\alpha \leq 0.05)$ for the practice level of strategic adaption on the practice level of economic crisis management strategies. It also shows that $\mathrm{R}$ Square is (0.521), which means that the dimensions of strategic adaption as a whole interpret $52.1 \%$ of the total economic crisis management strategies. It is a clear also that there is a statistically positive impact for adopting strategic change on economic crisis management strategies as a whole, as $t$ value is 8.117 with Sig 0.000 , also the dimension of interaction with the environment has statistically positive impact on economic crisis management strategies as a whole, since t value is 7.243 with Sig 0.000. Furthermore, strategic synergy has a statistically positive impact on economic crisis management strategies as a whole because $\mathrm{t}$ value is 8.545 with Sig 0.000 . T test indicates that all the coefficients are significant at $5 \%$ significance level, as values between 7.24 and 8.545 , which are higher than critical value (1.96).

The fourth questions: What are the procedures, which the ministries/ institutions have taken to address the current economic crisis?

According to respondents' answers about this question, the most important procedures, which have been taken by ministries, can be clarified to three categories as the following:

\section{Economic and trade procedures}

- Prevent the importation of many products that consume foreign exchange reserves such as new cars and luxury goods.

- $\quad$ Reliance on private sector companies to import materials that the Syrian government is not allowed to import due to economic sanctions.

- Contracting to import consumer goods, which are not existed in Syria in sufficient quantities from friendly countries such as Lebanon, Iran, Russia and China.

- $\quad$ Opening a credit line with Iran worth one billion dollars to provide oil derivatives and other goods.

- $\quad$ Reducing the prices of 1550 foodtypesfrom 10 to 40 per cent, 836 clothing from 10 to 50 per cent, 3269 household equipment, 289 manufacturing materials and 988 electric tools, by 15\%, also reducing the prices of 1204 types of detergents by $25 \%$.

- Tightening the rationing control on the markets through organizing a large number of ration punishments in all governorates on a daily basis.

- The training courses organized by the ministry for managers of companies and institutions in the field of development and administrative reform, and the courses for rationing supervisors to supply the trade directorates in the provinces with sufficient and effective food control cadres to tighten control on prices of goods and consumables in different markets.

- The opening of new halls for the Syrian institution for Trade and establishing a number of exhibitions in those halls, such as the exhibition of stationery and school supplies and others, and selling at low prices comparison with private sector.

- The Ministry has automated the work systems of grain distribution centers in the governorates and monitored the centers with cameras to prevent waste. 


\section{Financial and monetary Procedures}

- Pumping part of the foreign exchange reserves in the markets to adjust the exchange rate of the Syrian lira.

- Increase allocations of running spending in the state budget significantly at the expense of investing spending in order to cover the expenses of war.

- The flexibility in the monetary policy procedures according to the new circumstances, where the central bank of Syria has determined a interest rate of $7 \%$ on deposits in banks for a month, and considering it the reference price which through it the interest rates have been determined on the rest of the periods. And also identifying the interest rate on investment certificates was by 10 percent, while the deposits for more than one month have not been determined, as it is up to the working banks to determine this according to their vision and their need for liquidity. The banks were previously required at the beginning of the crisis at fixed rates for each specific period of time (7 percent from 1 to 3 months, 8 percent from 4 to 6 percent, 9 percent from 7 to 9 months, 10 percent from 10 a Month to year, 10 percent up to 20 percentfor more than 1 year). In addition, full freedom to deposit money in banks with foreign currencies and withdraw them with their accrued interest after it was not allowed at the beginning of economic crisis.

- Allowing recently the money transfer in foreign currency to Syria and receiving them in cash in foreign currency. While the previous procedure forced the owners of remittances to receive their money in Syrian pounds.

\section{Administrative procedures}

- Activate the one-stop shop for investors to facilitate and accelerate investment procedures and make them limited to one place.

- Establishing new centers under the name of Citizen Service Center to facilitate procedures for citizens.

- Establish many vocational rehabilitation courses to provide job opportunities for the unemployed.

The fifth question: What are the obstacles, which have faced the ministries/institutions in managing the crisis?

Based on respondents' answers about this question, the most important obstacles, which have faced ministries/ institutions, were as the following:

- The problem of smuggling through the entering a lot of smuggled materials to the Syrian markets in illegal ways and harmful to the local product.

- Continuous volatility of the exchange rate of the Syrian lira against the dollar.

- The sharp decline in the country's foreign exchange reserves to reach $\$ 700$ million after it was $\$$ 18 billion before the war.

- $\quad$ Lack of skilled labor as a result of the migration of a large number of young people and scientific qualifications outside the country as a result of the war.

- Exacerbating the financial and administrative corruption in various economic sectors due to the war conditions.

- Decline the industrial and agricultural production significantly during the crisis years.

- Trade balance deficit through a significant drop in exports.

- The decline in revenues of the state budget, therefore the worsening of the state budget deficit. 
- The harsh economic sanctions imposed by the European Union and Western countries on Syria in the energy, oil, financial and commercial sectors.

- Stop the foreign investments and departure of a significant number of domestic investments outside Syria.

\subsection{Test hypothesis of the study}

h. There is a positive correlation between practice strategic adoption and economic crisis management strategies under the circumstances of the Syrian war.

The (14)

In order to test hypothesis of the study, Pearson correlation was used as the following table illustrates:

The table (14) indicates that there is a positive correlation between strategic adoption and economic crisis management strategies, and this result enhances the last result on existence of a statistically significant impact between both variables. Therefore, hypothesis of the study is accepted.

\section{Conclusion}

Pearson Correlation between strategic adoption and crisis management strategies

\begin{tabular}{llcc}
\hline & & $\begin{array}{c}\text { Strategic } \\
\text { Adoption }\end{array}$ & $\begin{array}{c}\text { Crisis } \\
\text { Management }\end{array}$ \\
\hline Strategic & Pearson Correlation & 1 & $* * 672$. \\
Adoption & Sig. (2-tailed) & & 000. \\
& $\mathrm{~N}$ & 15 & 116 \\
\hline Crisis & Pearson Correlation & ${ }^{* *} 672$. & 1 \\
Management & Sig. (2-tailed) & 000. & \\
& $\mathrm{~N}$ & 116 & 15 \\
\hline
\end{tabular}

There is no doubt that the long experience gained by the Syrian economic planner in dealing with the crises and economic siege of the last century, the diversification of the Syrian economy before the war and its ability to build an effective network of relations with important international parties have played a role in the economy's steadfastness in the current crisis. These insights have been embodied through the results of the current study from a strategic perspective by demonstrating a good level of flexibility and rapid response to government institutions, which has manifested in the search for alternatives and contingency plans for each stage. In addition to an acceptable level of strategic adaption of Syria's economic decision-maker during the crisis years, which has enabled the state to coexist with and manage the crisis, by the way which prevented the collapse economy, stopping it at a certain level of decline, and then begin a gradual recovery. The significant lesson from this study for those involved in the economic affairs of the countries, is to benefit from its findings and recommendations and to work on building the economy and preparing it to be flexible and strategically adaptive in a way that allows it to face any crisis, no matter how severe, by diversifying the sources of state income, balancing all sectors of the economy and adopting an appropriate economic model to the circumstances and nature of the country, away from the ready molds and full economic dependence of other countries, taking into account benefit from the experiences of others to avoid the occurrence of similar economic crises to those which occurred in some countries.

\section{Recommendations}

The study provides recommendations based on the results of the study, in addition to general recommendations will benefit the Syrian economy from the researcher's perspective :

- Forming a committee of senior experts from the six ministries/institutions to develop adaptive strategies for managing the crisis and review them periodically every 6 months. 
- Creation of boundary spanning units at the six ministries and institutions considered to interact more with the external environment to adapt appropriately to changes and crisis as they occur and exceed them.

- Giving a bigger role to the State Planning Commission, which makes it has the tools that enable it to predict the surrounding environment and plan for the state on this basis.

- Reducing the domestic demand of foreign exchange through control of imports, seizure of smuggling operations, and speculation.

- Creating the reserve fund under the supervision of the Central Bank for use only in times of crisis through the allocation $2 \%$ of the annual government budget, and this fund is different from the foreign exchange reserve in the Central Bank.

- Transform all profitable state companies into a participatory system in accordance with the shares of stocks with the private sector.

- Reviewing the structure of interest rates on deposits and loans in Syrian Lira and US Dollar.

- Support the national industry and export by helping exporters reach potential markets through agreements with friendly countries eig. Iran, Iraq, China, Russia ...etc for securing the participation of Syrian companies in foreign exhibitions.

- $\quad$ Forming a special office to attract the funds of Syrians from abroad for investments through certain facilities and procedures, which are estimated at more than $\$ 100$ billion, according to economic experts.

- Creating a modern and fair tax system that attracts investments and solves the problem of weak revenues and tax evasion.

- Combating the administrative corruption by accelerating the transition to e-government system. 


\section{REFERENCES}

- $\quad$ Abu Rumman, S. (2016). The Impact of Transformational Leadership in Preparedness to Crisis Management, Jordan Journal of Business Administration, Vol.12, No.3, pp.713-729.

- Brent, R. (2004), “Chaos, crises and disasters: A strategic Approach to crises management in the tourism industry", Journal of Tourism Management, Vol.25, No. 6, pp. 669-683.

- Coombs, W. T. (2012), "Ongoing crisis communication: planning, managing, and responding" (3ed).California, Sage Publications.

- Damasucs center for research and Studies. (2016), "The effects of the crisis in the Syrian economy from 2011 to 2015" Damascus.

- $\quad$ Fearn-Banks, K. (2007), 'Crisis Communications: A casebook approach.”(3ed). NJ, USA.

- Gardi, N. (2017), "The Secret of the Syrian Economy's Steadfastness in the War",Al Nahda Journal, Vol.12, No.23,pp. 276-294.

- $\quad$ Gilpin. D, Murphy.P. (2008).Crisis management in complex world, New York, USA. Oxford University.

- Jaffar, Y. (2017), "The Impact of Strategic Planning in Crisis Management, Empirical Study of Public Institutions in the Area of Jerusalem Suburbs",Al Aqsa Unıversıty Journal - Humanities Series, Palestine, Vol. 21, No.1, pp. 293-324.

- Janssen, C and Brumby, D. (2015), "Strategic Adaptation to Task Characteristics, Incentives, and Individual Differences in Dual-Tasking", Journal of PLOSONE, Vol.10, No.7,pp.1 - 32.

- $\quad$ Al Kubaisy, S and Hussien, A. (2013). The Role of Strategic Planning in Effectiveness of Crises Management. The Journal of Administration \& Economics, No. 94, pp. 253-275.

- Lusia, H. (2013), “Crisis Management: Determining Specific Strategies and Leadership Style for Effective", Asian Journal of Management Sciences and Education, Vol. 2, No.2.

- Mykhailivna, K. (2016), "Theoretical aspects of strategic adaptation management of enterprises."Economic processes management, Vol. 4, No.3, pp. 1-8.

- Tayauova, G. (2011), “The Impact of International Entrepreneurial Orientation on Strategic Adaptation",Procedia Social and Behavioral Sciences, Vol. 24, No.2, pp. 571- 578.

- $\quad$ Al Sirafi, M. (2008), “Crisis management”,Hurus institution forpunlication, Alexandria, Egypt.

- Unlu, A., Kapucu, N and Sahin, B.(2010). Disaster and crisis management in Turkey: a need for a unified crisis management system, Journal of Disaster Prevention and Management, Vol. 19, No. 2.

- $\quad$ The World Bank in the Syrian Arab Republic. (2018). Available on the website of the World Bank: https://www.worldbank.org/en/country/syria/overview 